University of San Diego

Digital USD

Theses

Theses and Dissertations

3-2017

\title{
Plasma metabolites reveal changes in physiological state of Eared Grebes (Podiceps nigricollis) during three non-migratory periods
}

\author{
Allison A. Yoshida \\ University of San Diego
}

Follow this and additional works at: https://digital.sandiego.edu/theses

Part of the Exercise Physiology Commons, Marine Biology Commons, Ornithology Commons, Poultry or Avian Science Commons, Terrestrial and Aquatic Ecology Commons, and the Zoology Commons

\section{Digital USD Citation}

Yoshida, Allison A., "Plasma metabolites reveal changes in physiological state of Eared Grebes (Podiceps nigricollis) during three non-migratory periods" (2017). Theses. 17.

https://digital.sandiego.edu/theses/17

This Thesis: Open Access is brought to you for free and open access by the Theses and Dissertations at Digital USD. It has been accepted for inclusion in Theses by an authorized administrator of Digital USD. For more information, please contact digital@sandiego.edu. 
UNIVERSITY OF SAN DIEGO

San Diego

\section{Plasma metabolites reveal changes in physiological state of Eared Grebes (Podiceps nigricollis) during three non-migratory periods}

A thesis submitted in partial satisfaction of the requirements for the degree of

\section{Master of Science in Marine Science}

By

Allison A. Yoshida

Thesis Committee

Hugh I. Ellis, Ph.D., Thesis Chair

Mary Sue Lowery, Ph.D.

Judy St. Leger, D.V.M

2016 
The thesis of Allison A. Yoshida is approved by:

\section{Hugh I. Ellis, Ph.D., Thesis Committee Chair University of San Diego}

Mary Sue Lowery, Ph.D., Thesis Committee Member University of San Diego

Judy St. Leger, D.V.M., Thesis Committee Member SeaWorld Adventure Park

University of San Diego

San Diego

2016 
Copyright 2016 Allison A. Yoshida 


\section{ACKNOWLEDGMENTS}

This thesis could not have been completed without the help, support and guidance of many people. Firstly, I would like to thank my thesis committee chair Dr. Hugh Ellis for his guidance throughout this entire project from forming the project to reading the final edits. Thank you to my thesis committee Drs. Sue Lowery and Judy St. Leger for your contributions to the thesis and giving me additional laboratory experience. In addition to my committee, I would like to thank Dr. Scott McWilliams and Jaqueline Hall of the University of Rhode Island who not only ran the plasma samples in his lab, but also provided many rounds of insightful edits. Thank you to Annette Henry and Dr. Joseph R. Jehl who provided me with valuable knowledge about Eared Grebes. I would also like to thank Drs. Vincenzo Ellis and Adam Siepielski for guidance in my statistical analysis. I greatly appreciate the time and effort you have all invested into my thesis.

I am grateful to have had funding from many sources that allowed me to complete multiple field research trips and sample collections. The Valentine Eastern Sierra Reserve Research Grant made many of my trips to Mono Lake possible. I would also like to Graduate Women in Science and Drs. Hugh Ellis and Scott McWilliams for providing financial support. Lastly, I would like to thank the Environmental and Ocean Science Department at the University of San

Diego for not only financially supporting this project, but also for giving me a job every year I was there.

There were many people who were instrumental in helping me collect my samples in all locations. I am very grateful to Tom Crowe who acted as boat 
driver, grebe locator, and grebe shooter over the three years I collected samples. I would also like to thank Tom Anderson at Salton Sea, and John Neill and Kyle Stone at Great Salt Lake for being instrumental in live grebe capture. Fellow graduate students Branda Cook and Samanatha San Francisco also helped in grebe capture and sampling. Thank you to you both not only for your help in the field, but for your moral support as well.

Apart from those who helped with the project directly were many people who supported me throughout this project. I would like to thank the Marine Science faculty for lending and ear and offering helpful advice. I am also grateful to Kathleen Andrews, Elizabeth Baker-Treloar, and Keith Fink who were not only amazing people to work for in the Environmental and Ocean Sciences Department, but also very supportive during challenging times. Thank you also to my fellow graduate students, especially Charlene Renck and Danielle Carter for your friendship, support, and helping keep my sanity.

Last but certainly not least I would like to thank my family for enduring through these tough years with me, and not giving up on the idea that I might one day finish this. Your encouragement and support (financial and emotional) has meant the world to me. 


\section{TABLE OF CONTENTS}

List of Tables...........................................................

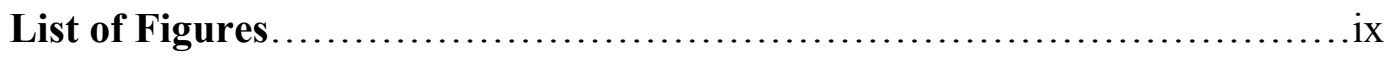

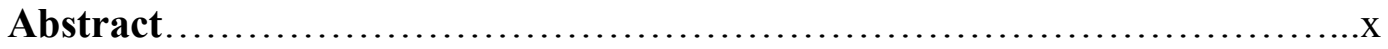

Chapter 1: General Introduction...................................

Eared Grebes....................................................2

Annual Cycle and Body Composition...............................2

Migration and Nutrition...........................................5

Eared Grebe Energetic Costs....................................

Plasma Metabolites..............................................9

Chapter 2: Plasma Metabolites Reveal Changes in Physiological State of

Eared Grebes (Podiceps nigricollis) During Three Non-migratory Periods...11

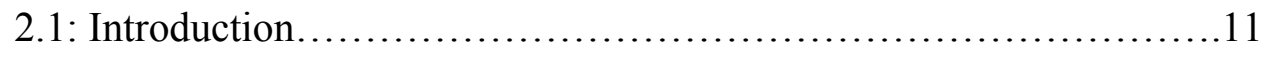

2.2: Materials and Methods........................................18

2.2.1: Study Areas..........................................18

2.2.2: Field Sampling and Blood Collection...................18

2.2.3: Blood Processing....................................19

2.2.4: Plasma Metabolite Analysis............................20

2.2.5: Statistical Analysis.................................20

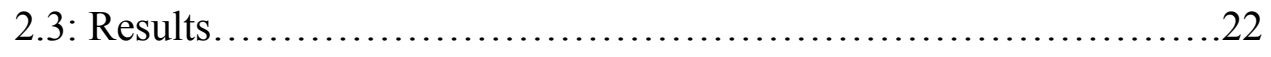

2.4 Discussion..................................................... 34

2.4.1: Resting and Active Staging Grebes at Great Salt Lake......34

2.4.2: Staging at Mono Lake and Great Salt Lake................35 
2.4.3: Extended Stopover at Salton Sea..

2.4.5: Comparisons to Other Species During Migratory Periods..40

Chapter 3: Summary.............................................45

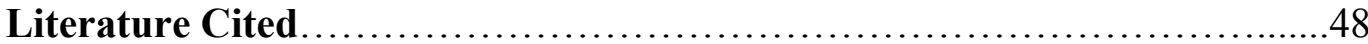




\section{LIST OF TABLES}

Table 2.1: Eared Grebe plasma metabolite sample sizes (n) and means ( \pm SE) of triglyceride (TRIG), uric acid (URIC), beta-hydroxybutyrate (BUTY), and glycerol (GLY) at Mono Lake, Great Salt Lake, and Salton

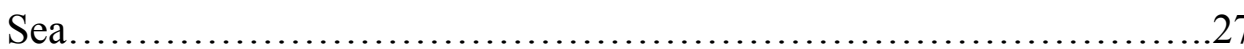

Table 2.2: Plasma metabolites during various periods of the annual cycle for various species or groups of species of migratory birds compared to those

for resting and actively swimming Eared Grebes......................44 


\section{LIST OF FIGURES}

Figure 2.1: Generalized annual migration route of Eared Grebes in North America

Figure 2.2: Mean concentrations of triglycerides, beta-hydroxybutyrate, uric acid and glycerol for actively staging grebes at Great Salt Lake and resting grebes held overnight......................................25

Figure 2.3: Plasma metabolites measured at three non-migratory periods during fall staging at Mono Lake, late-winter staging at Salton Sea, and spring staging at Great Salt Lake

Figure 2.4: Relationship between body mass and triglycerides for Eared Grebes residing at three important sites used during the non-migratory, nonbreeding period of their annual cycle.

Figure 2.5: Relationship between body mass and uric acid for Eared Grebes residing at three important sites used during the non-migratory, nonbreeding period of their annual cycle 


\begin{abstract}
Energy storage and use during the annual cycle of migratory birds is dynamic especially during migration. However, considerable amounts of the annual cycle are spent not migrating, and the physiological state of birds during these non-migratory periods is not well understood. We compared plasma metabolites (TRIG, BUTY, URIC, GLY) in Eared Grebes (Podiceps nigricollis) residing at three important areas when they are not migrating: fall staging (postbreeding at Mono Lake, California), spring staging (pre-breeding at Great Salt Lake, Utah), and an extended stopover prior to spring staging (Salton Sea, California). Plasma metabolites were also measured in resting and active grebes while staging at Great Salt Lake. As expected, grebes held overnight without food had decreased plasma TRIG and URIC, but elevated plasma BUTY, compared to active grebes. Grebes showed the greatest change in physiological state during late-winter at Salton Sea, California when elevated plasma TRIG levels indicated increased fat deposition. Body mass in Eared Grebes was positively correlated to plasma TRIG and URIC at the two staging areas, but not the extended stopover site. Differences in physiological state during non-migratory periods over the annual cycle of Eared Grebes puts current plasma metabolite studies during migration periods into context and provides an example of the importance of nonmigratory periods for acquisition of nutrient stores.
\end{abstract}




\section{CHAPTER 1. GENERAL INTRODUCTION}

Migratory birds employ a diverse range of strategies in their annual cycle including both migratory and non-migratory periods. Species migrate for optimal nutritional resources or climate. The character of the migration can vary dramatically in both flight duration and nutritional storage. The Bar-tailed Godwit (Limosa lapponica) flies 11,000 km from Alaska to New Zealand without stopping, yet can have four staging areas each lasting approximately forty days during the vernal migration back to breeding grounds (Gill et al. 2005). A different migration strategy is used by Blackcaps (Sylvia atricapilla). Blackcaps utilize multiple short term refueling stops that last only hours to a couple of days to complete their annual cycle (Gannes 2002). Regardless of the migration strategy used, birds must fuel their flight from nutritional stores acquired before leaving on a non-stop migration or at stopover sites along a migration route. Nonmigratory periods can be energetically expensive consisting not only of building up nutritional stores, but engaging in costly activities, including molting, and for some species, long flights in search of food. In the case of waterbirds, these activities may include swimming and diving as well as rapid molting of all flight feathers simultaneously. The physiological condition of birds during nonmigratory periods is not well established because the majority of studies have focused on the migratory periods that include quick refueling stops and periods immediately following a migratory flight.

Plasma metabolite profiling is a method that has been used in many studies to determine a bird's physiological condition. These studies demonstrate 
that fat is the primary energy source used by migrants during migration (Ramenofsky 1990); however few have focused on the physiological state during non-migratory phases not related to reproduction, (an exception is Jenni-Eiermann and Jenni 1996). The over-arching goal of this research is to understand a waterbird's nutritional state during its non-migratory periods.

Eared Grebes

Eared Grebes are migratory waterbirds primarily found in the northwestern part of North America, but also in parts of Europe and Africa. They spend most of their time in large flocks on hypersaline lakes and ponds (Cullen et al. 1999). Though they migrate, they spend only two to three months of the year flying. The other nine to ten months they are flightless, their flight muscles too atrophied to fly. Instead they are active swimmers and foot-propelled divers feeding on invertebrates such as brine shrimp (Artemia spp.), alkali flies (Ephydra spp.), and pile worms (Neanthes succinea) (Jehl 1988; Caudell and Conover 2006; Anderson et al. 2007). Given their poor wing-loading and short tail feathers, Eared Grebes are much better adapted to foot-propelled swimming and diving than flight (Cullen et al. 1999; Jehl et al. 2003).

\section{Annual Cycle and Body Composition}

Over the course of a year, grebes migrate as much as $6,000 \mathrm{~km}$ broken into four migrations. A southern migration follows the summer breeding period in the northwestern United States and southwestern Canada; this migration takes the grebes to fall staging areas where they molt their flight feathers and put on fat. Although fall staging occurs in many places, the vast majority of grebes go to 
either Mono Lake in California or Great Salt Lake in Utah (Storer and Jehl 1985; Jehl 1988). They spend as long as four months on these lakes during the fall staging period, feeding until food resources are depleted. Fall staging is followed by another southbound migration primarily to the Gulf of California for the winter (Cullen et al. 1999; Ellis and Jehl 2003; Jehl et al. 2003; Jehl and Henry 2010). In late winter and early spring, a vernal migration brings them back north to Great Salt Lake, Utah. An unknown portion of those grebes stop at Salton Sea, California for about a month before continuing on to Great Salt Lake (Cullen et al. 1999; Jehl and Henry 2010; San Francisco 2016). Spring staging occurs at Great Salt Lake usually through May. The grebes molt into breeding plumage and go through courtship before dispersing to their breeding grounds for the summer (Cullen et al. 1999).

The morphology and body composition of Eared Grebes change considerably over their annual cycle. Jehl (1997) described a volant body composition in migratory grebes that differed considerably from their flightless condition when on the water. The major shifts that occur involve fluctuations in body mass, particularly due to changes in breast muscle and digestive organ size and the laying on of fat. The migratory condition of grebes is characterized by large pectoral muscles and a smaller gut with an adult body mass ranging from $250-450 \mathrm{~g}$. In contrast, during periods of flightlessness (breeding, staging, extended stopover and wintering) grebes can weigh as much as $735 \mathrm{~g}$. Generally their hearts are small with more muscular legs to support swimming, diving, and 
courtship displays on the water. Digestive viscera (stomach, intestine, liver, and also kidney) hypertrophy following a pectoral muscle atrophy (Jehl 1988).

Flightless grebes during fall staging in Great Salt Lake or Mono Lake reach their largest size in their annual cycle. Fall staging in particular may be characterized into three phases, early, hypertrophic, and late as first described by Bergen (2003). Essentially Eared Grebes arrive at fall staging areas low in mass (250 - $300 \mathrm{~g}$ ) and undergo breast muscle atrophy; these are the early birds. They can be referred to as hypertrophic when they begin feeding so voraciously they may become too fat to fly (>450 g, according to Jehl and Henry 2010) if they had large pectoral muscles. Late birds lose mass including fat before departing for the winter (Jehl 1988, 1993). During this late phase of fall staging, the pectoral muscles enlarge and the digestive organs begin to atrophy (Jehl et al. 2003); departure mass probably cannot exceed $450 \mathrm{~g}$ in the volant condition (Jehl and Henry 2010). The loss of about $150 \mathrm{~g}$ of lean mass and fat coupled with shrinking of digestive organs is something not commonly seen in other species directly prior to migration (Jehl 1997; Jehl et al. 2003).

Plumage also changes between migratory and flightless conditions. While body molt occurs throughout the annual cycle, fight feathers only molt in the early during fall staging. Adults in the summer breeding season are in breeding plumage, red eyes, black and brown wings with gold brown feathers behind the eyes that resemble ears (Storer and Jehl 1985).

The rapid changes in body composition just prior to a migration and immediately following one suggests important changes in physiological state 
between the volant and nonvolant condition of these birds. How these inefficient flyers (Jehl et al. 2003) manage to migrate each year must be correlated to changes in their physiological state during or near the end of the non-migratory periods. Nutritional stores have not been previously studied in Eared Grebes, but they have been well documented in other migrants, like passerines and shorebirds (McWilliams et al. 2004; Guglielmo et al. 2005)

\section{Migration and Nutrition}

It is generally accepted that migratory birds primarily use fats (lipids) to fuel migration. Fatty acids from adipose tissue are transported from both adipocytes and the liver through the circulatory system to muscles to sustain the high intensity action of flight (McWilliams et al. 2004). Studies by Ramenofsky (1990) as well as Jenni and Jenni-Eiermann (1998) demonstrate why fats and particularly fatty acids are the fuels used by birds even though this is not the case with mammals where carbohydrates are the primary source. Fatty acids, have on average nine times more energy per gram than carbohydrates and proteins, and also have a much lower water content $(5 \%$ and $70 \%$ respectively; Ramenofsky 1990; Jenni and Jenni-Eiermann 1998). By using fatty acids, birds are able to store more energy per unit of mass and get more energy in a small space than other fuel types. This is especially crucial for flight when wing load plays a major factor.

Proteins have also been shown to be used during migration, however not nearly to the extent of fats. The amount of energy used in flight contributed by protein varies from 5-15\% (Jehl et al. 2003; McWilliams et al. 2004), and it is 
most heavily consumed in the first 20 min of flight before fatty acid pathways are fully functioning (Gerson and Guglielmo 2013). Protein catabolism may act to replace Krebs cycle enzymes during fat metabolism and to provide metabolic water during flight (Jenni and Jenni-Eiermann 1998; Klaassen 1996; Klaassen et al. 2000). Although birds begin migrations with up to $50 \%$ of their body mass as fat stores, if those stores become depleted, proteins primarily from digestive organs are used to supply additional fuel toward the end of migration (Piersma and Jukema 1990; Ramenofsky 1990; Lindstrom and Piersma 1993; McWilliams and Karasov 2001). Carbohydrates like glycogen are generally thought to be relatively insignificant as a migratory fuel; however, they may be used in the beginning stages of flight before fat metabolism begins (Schwilch et al. 1996; Jenni-Eiermann et al. 2001; Gerson and Guglielmo 2013).

Studies conducted on fuel use during migrations and at refueling sites are based mostly on long-distance passerines and shorebirds. Many of the species in these studies, such as the Reed Warbler (Acrocephalus scirpaceus), stop at refueling sites along their migration routes so they can replenish fuel stores before moving on. It is important to distinguish between stopover sites and staging sites, to understand different migration strategies. Stopover sites are used for short periods lasting from a few hours to a few days whereas staging periods last upwards of 50 or more days and involve the acquisition of larger nutritional stores than at stopover sites (Warnock 2010). In addition, staging areas may serve other purposes. Eared Grebes exemplify waterbird migrants using staging areas. Fall staging at Mono Lake and Great Salt Lake allow them to complete a full flight 
feather molt in addition to building nutritional reserves. Spring staging at Great Salt Lake provides a time for molting into breeding plumage, courting and pairing, as well as building up reserves for their flight out to breeding areas and perhaps even for egg production. However, Salton Sea is characterized as an extended stopover. Grebes typically spend less than 50 days there, and use Salton Sea to replenish nutritional stores before migrating north. Furthermore, they undergo a body composition change away from the migrant condition upon landing and regain the migrant body composition prior to departure (Jehl 1997). Although grebes acquire fuel stores there just as they do at their staging areas as demonstrated by their weight gain, they do not spend several weeks at Salton Sea as they do at Mono Lake and Great Salt Lake (Jehl and Henry 2010). It is presumed that some grebes migrate to Great Salt Lake in the spring without the need to stop at Salton Sea (Cullen et al. 1999).

Eared Grebe Energetic Costs

Eared Grebes preparing for migration carry up to $46 \%$ of their mass as fat, a higher percentage of fat than a staging bird of the same mass (J.R. Jehl and H.I. Ellis, unpublished data). This would suggest grebes are storing migratory fuel (fats) for their long flight.

As with other migratory species, flight is very energetically costly for Eared Grebes. It may be almost two times as costly. The average cost of flight for most migrants is around 11 times basal metabolic rate (BMR) (Goldstein 1990), but for Eared Grebes it has been estimated to be as high as 17.9 times BMR based on body mass changes and using $95 \%$ fat and $5 \%$ protein as their 
energy source (Jehl et al. 2003). It is unknown to what extent fats, proteins, and carbohydrates are consumed, stored, or used during various periods of their annual cycle. Plasma metabolite analysis has become a chosen method for studying the nutritional status of a wild bird from only a single capture and blood sample. Capture and sampling of Eared Grebes during migration has proven to be logistically very difficult due to night migration and sampling constraints. Nonmigratory Eared Grebes, though difficult to capture, are more accessible; and they also demand appreciable energy during this time. Insight into nutritional store use during non-migratory periods can highlight the importance of the non-migratory phases for nutritional storage and physiological state throughout the annual cycle. It can also suggest when fuels used in migration are stored. A study of plasma metabolites in grebes during periods they are flightless may clarify whether these metabolites are deposited, stored, and used in similar or different ways than in migrating grebes. It will surely add new information to what we know about energetics of non-migrating grebes (Ellis and Jehl 2003; Conover and Caudell 2009). Time-activity budgets have been described for Eared Grebes at Mono Lake (Jehl 1988) and Salton Sea (San Francisco 2016). Based on behavioral energy equivalents (Ellis 1994), San Francisco (2016) created an energy budget for grebes at Salton Sea. She found the average daily energy budget for a flightless grebe is about 2.5 times its basal metabolic rate (BMR). Considering that Eared Grebes display the same activities (surface swimming, diving, preening, resting/sleeping) for the majority of the year and only migrate two to three months, it is reasonable that their physiological state during the non-migratory periods 
represents nutritional store use by Eared Grebes during the majority of their annual cycle.

\section{Plasma Metabolites}

Measurement of key plasma metabolites in the blood has been the primary method for determining a bird's nutritional condition during migration. Plasma metabolites are good indicators of a bird's physiological state at the time of blood sampling because certain metabolite concentrations increase or decrease in the blood during metabolism (Jenni-Eiermann and Jenni 1994). There are five key metabolites often used in migration energetic studies: triglycerides (TRIG), glycerol (GLY), ß-hydroxybutyrate (BUTY), free fatty acids (FFA), and uric acid (URIC). Each metabolite is an indicator of a specific metabolic process.

Triglycerides found in blood plasma are indicators of fat deposition. They are the stored form of lipids that are made in the liver and then transported to adipose tissue (Robinson 1970; Ramenofsky 1990). Elevated TRIG levels are often associated with migrants at a stopover and refueling site along a migration pathway when they are replenishing nutritional stores. TRIG is elevated during body mass increase in migrants and is often used as an indicator of body condition during migration (Jenni-Eiermann 1994; Jenni and Schwilch 2001; Williams et al. 2004; Landys et al. 2005).

TRIG in adipose tissue is broken down into glycerol and free fatty acids, which are released into the blood to be used elsewhere as energy sources. Elevated glycerol concentrations are thus indicators of fat breakdown. The presence of FFA in plasma is analogous to fatty acid oxidation (Scow and 
Chernick 1970; Hurley et al. 1986; Elia et al. 1987). Multiple studies on shorebirds and passerines strongly support elevated concentrations of GLY and FFA during migration and just after landing at refueling sites (e.g., Jenni-

Eiermann and Jenni 1991; Landys et al. 2005; Acevado Seaman et al. 2006).

Beta-hydroxybutyrate is a ketone body that is associated with fasting and fat breakdown. It is synthesized from free fatty acids and is thought to replace some glucose requirements when glucose runs low (Robinson and Williamson 1980). It is correlated to a decrease in mass in migrants (Jenni-Eiermann and Jenni 1994; Dietz et al. 2009).

Uric acid is an indicator of protein breakdown. These proteins can originate as both dietary proteins and intrinsic muscle tissue (Robin et al. 1988; Lindgård et al. 1992). Uric acid concentrations in migrants are similar between passerines and shorebirds; however, uric acid increases with duration of flight to cope with dehydration from lack of water-heavy carbohydrates suggesting protein use as a necessary fuel (Jenni-Eiermann and Jenni 1991; Landys et al. 2005; Gerson and Guglielmo 2013).

Measurement of plasma metabolites of Eared Grebes during active nonmigratory periods will not only elucidate the energy stores of grebes active in a non-migratory condition, but support a comparative baseline for plasma concentrations of migrants. These data will provide insight into how the use of certain fuel substrates during migratory periods correlates to the energetically demanding non-migratory phases. 


\section{CHAPTER 2. PLASMA METABOLITES REVEAL CHANGES IN}

PHYSIOLOGICAL STATE OF EARED GREBES (PODICEPS NIGRICOLLIS) DURING THREE NON-MIGRATORY PERIODS

\subsection{INTRODUCTION}

The nutritional condition of migratory birds is dynamic and changes considerably over the annual cycle. Birds acquire energy stores for migration often at intense rates while they reside at refueling and stopover sites during migration (Seaman et al. 2005; Acevado Seaman et al. 2006), but there are nonmigratory periods during the annual cycle such as breeding, staging, wintering, and molting when birds are active and also may use or acquire energy stores (Jenni-Eiermann and Jenni 1996; Done et al. 2011). Energy use during migration has been well documented by measuring fluctuations in key plasma metabolites that indicate a bird's nutritional condition at the beginning and end of migrations and at refueling stopover sites (e.g., Jenni-Eiermann and Jenni 1991, 1994;

Gannes 2001; Guglielmo et al. 2005; Lyons et al. 2008; Smith and McWilliams 2010). Fewer studies have used plasma metabolites to document changes in nutritional condition of migratory birds during the non-migratory periods of the annual cycle with most such studies focusing on the breeding (e.g., Giudici et al. 2010; Done et al. 2011) or molting periods (e.g., Jenni-Eiermann et al. 2002). Generally, little is known about plasma metabolites in birds during non-migratory periods outside the breeding season; still less is known about waterbirds during this time. This study looks at plasma metabolites of Eared Grebes (Podiceps nigricollis), a diving waterbird, in order to fill in that picture. 
Investigation of nutritional condition of waterbirds during the nonmigratory periods is important because they are actively foraging, swimming, diving, and preening while they must also maintain adequate body stores of fat and protein. Spatial differences in habitat quality or temporal differences in strategy of fuel storage may be revealed by comparisons of physiological state over space and time (Anteau and Afton 2009, 2011; Thomas and Swanson 2013). Information on fuel use during these non-migratory periods also provides the necessary context for a more complete understanding of avian fuel use throughout the entire annual cycle. We used plasma metabolites to compare changes in the physiological state of Eared Grebes during three different non-migratory periods:

(1) at a fall staging area (Mono Lake, California), (2) at a prolonged stopover (Salton Sea, California), and (3) at a spring staging area (Great Salt Lake, Utah) (Fig. 2.1). Staging areas in this context, as described by Warnock (2010), refer to extended stays of at least 50 days in areas other than breeding and wintering sites during which time there may be substantial changes in body composition and the digestive system. Only some of the grebes flying to Great Salt Lake stop at Salton Sea on their migration north. They typically stay at least 30 days (San Francisco 2016), and go through a similar body composition changes upon arrival and again upon departure (Jehl 1997) as seen in grebes at Mono Lake and Great Salt Lake. For these reasons, Salton Sea is best described as an extended stopover rather than either a typical refueling or a traditional staging site. The body changes seen in Eared Grebes as they switch from a migrant condition to a swimming existence on the water are among the most dramatic and profound body composition 
changes reported for any migrating bird (Jehl 1997). One notable aspect of the change from a migrant condition is the loss of flight. The flightlessness of grebes is associated with pectoral atrophy (Gaunt et al. 1990, Jehl 1988, 1997, 2007) exacerbated by excessive weight gain due to extreme hyperphagia associated with hypertrophy of their digestive viscera (gizzard, intestine, liver) and kidneys, as well as accumulation of fat stores (Jehl 1997). Once their food at a given staging area becomes depleted, they stop or reduce feeding, undergo pectoral hypertrophy accompanied by wing flapping, and lose weight, especially from reductions in mass of the viscera (Jehl 1997, 2007; Jehl and Henry 2010). Although the pattern of body mass changes is the same at Salton Sea, their departure is unrelated to food depletion.

The annual phenology of movements of Eared Grebes involves spending nine or more months a year on bodies of water throughout western North America, punctuated by long, non-feeding migrations between such areas (Fig. 2.1). This pattern, described by Cullen et al. (1999) and Jehl et al. (2003), is different from that of many birds where breeding and wintering are separated by relatively rapid, seasonal migrations between the main breeding and wintering areas. By contrast, Eared Grebes leave breeding areas at the end of summer and go to fall staging areas (primarily Mono Lake and Great Salt Lake, each of which may have a million or more birds) to molt flight feathers and put on fat. However, they may extend their stay until the superabundant invertebrate prey is eventually depleted (Jehl 1997). Usually this happens in November to December each year, although grebes have extended their stay at these fall staging areas until January (Jehl 
1988). Once they leave these areas in the fall, grebes travel primarily at night to the Gulf of California and a few other locations where they spend the winter. They leave the Gulf beginning in February and fly north, ultimately to Great Salt Lake. An unknown and variable proportion of them stage at Salton Sea prior to moving to Great Salt Lake (Jehl and McKernan 2002). Although some grebes are in breeding plumage at Salton Sea, most of that incomplete molt (no replacement of flight feathers) happens at Great Salt Lake, where courting and pair formation occur. Eared Grebes are present at Great Salt Lake in April and May, after which they disperse to breeding locations (Jehl et al. 1999). Because they do not feed during migration (Cullen et al. 1999), Eared Grebes rely on nutrient stores acquired during their staging and other non-migratory phases to fuel these migratory flights.

The objectives of my study were to compare changes in the physiological state of Eared Grebes, as indicated by four plasma metabolites; triglycerides (TRIG), beta-hydroxybutyrate (BUTY), uric acid (URIC), and free glycerol (GLY) during three non-migratory periods (fall staging at Mono Lake, a extended stopover at Salton Sea on the vernal migration to Great Salt Lake, and spring staging at Great Salt Lake). We then compared the physiological state of grebes during these periods with those of other species during migratory periods. Each of the four measured metabolites we studied indicates a bird's physiological state at that moment. Plasma triglycerides are elevated when birds deposit fat (Robinson 1970; Ramenofsky 1990); beta-hydroxybutyrate is elevated when birds are catabolizing stored fat (Robinson and Williamson 1980); uric acid is produced 
during protein breakdown (Robin et al. 1988; Lindgård et al. 1992); and glycerol indicates fat catabolism, but also is elevated with triglycerides during intense fat deposition (Hurley et al. 1986; Cherel et al. 1988; Guglielmo et al. 2005). 
Figure 2.1. Generalized annual migration route of Eared Grebes in North America indicating breeding distribution in grey, staging and study locations $(\mathrm{ML}=$ Mono Lake, California; GSL $=$ Great Salt Lake, Utah; and SS = Salton Sea, California). Gulf of California (Gulf of CA) is the main wintering location. Solid arrows represent fall/southward migration route and dashed arrows represent spring/northward migration route. 


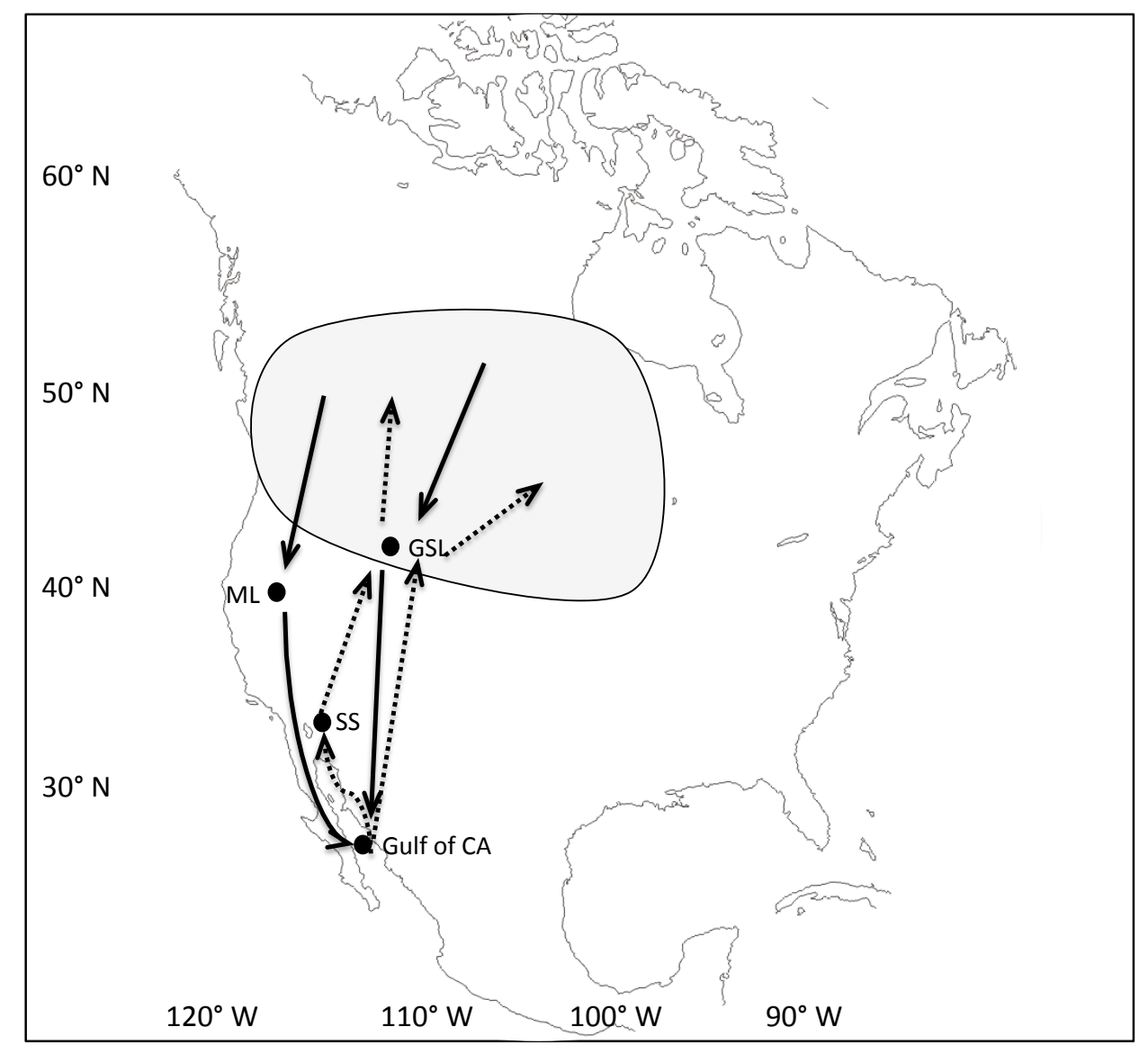




\subsection{MATERIALS AND METHODS}

\subsubsection{Study Areas}

Mono Lake, Salton Sea, and Great Salt Lake are all hypersaline, endorheic lakes, with large invertebrate populations during the times Eared Grebes are present. Mono Lake $\left(38^{\circ} \mathrm{N}, 119^{\circ} \mathrm{W}\right)$ is a $180 \mathrm{~km}^{2}$ alkaline $(\mathrm{pH}=9.8)$ lake on the eastern edge of the Sierra Nevada Mountain range. It has an average depth of 17 $\mathrm{m}$ and a salinity of $88 \mathrm{ppt}$ (Jellison and Melack 1993). The Salton Sea (33 ${ }^{\circ} \mathrm{N}$, $\left.116^{\circ} \mathrm{W}\right)$, in the northern part of the Sonoran Desert, is the largest lake in California covering $1,360 \mathrm{~km}^{2}$. Like Mono Lake it is alkaline $(\mathrm{pH}=8.5)$. Its salinity is higher than the ocean at $55 \mathrm{ppt}$ with a maximum depth of $13 \mathrm{~m}$ (Jehl and McKernan 2002). Great Salt Lake $\left(41^{\circ} \mathrm{N}, 114^{\circ} \mathrm{W}\right)$ is the largest of the three lakes $\left(4,400 \mathrm{~km}^{2}\right)$, but also the most shallow with an average depth of only $5 \mathrm{~m}$ and, like the other lakes, is alkaline $(\mathrm{pH}=10)$ and hypersaline with a salinity of 140 ppt (Lall and Mann 1995). Mono Lake and Great Salt Lake are at elevations exceeding 1,000 m, but Salton Sea is below sea level. Mono Lake and Great Salt Lake also have abundant brine shrimp (Artemia spp.) and alkali flies (Ephedra spp.) when the grebes are present, while Salton Sea has large numbers of introduced pile worms (Neanthes succinea) upon which the grebes feed.

\subsubsection{Field Sampling and Blood Collection}

Twenty-two fall staging birds were shot at Mono Lake during September and October of 2011 and in October of 2012 and 2013. Eleven birds were shot at Salton Sea in March of 2012, and eight at Great Salt Lake in May 2012. Nine additional birds were captured alive using a drive-by netting technique developed 
by Caudell and Conover (2007). The net was $100 \mathrm{~m}$ long and $2 \mathrm{~m}$ deep in the water when deployed by boat. Bird collection and sampling was done under U.S. Fish and Wildlife, California Fish and Game, and Utah Department of Natural Resources permits and complied with the Institutional Committee for the Care and Use of Animals at the University of San Diego.

No more than $300 \mu \mathrm{L}$ of blood was collected from live caught birds from the brachial or femoral vein using a heparinized 25 gauge butterfly needle. Blood was collected from shot birds using a heparinized 23 gauge needle. Body mass, plumage, tarsal length, and bill length were measured in all birds. All blood samples were collected $\leq 7 \mathrm{~min}$ after capture for live birds and usually more quickly for shot birds.

A separate group of nine Eared Grebes were live-captured at Great Salt Lake and placed in individual 5 gallon buckets lined with newspaper and covered with a towel. They were held overnight between 12 and $16 \mathrm{~h}$ without food. Each bird was weighed and bled in the morning and then released immediately back on the lake. These grebes are referred to throughout this paper as "resting" birds.

\subsubsection{Blood Processing}

Blood was transferred from syringes into $300 \mu \mathrm{L}$ lithium heparin gel capillary collection tubes (RAM Scientific, Yonkers, New York) immediately after blood draw, and stored on ice for up to $3 \mathrm{~h}$. All blood samples were centrifuged for $10 \mathrm{~min}$ at $10,000 \mathrm{rpm}$ to separate plasma. Plasma was transferred to $1.5 \mathrm{~mL}$ Eppendorf tubes on dry ice, and stored at $-80^{\circ} \mathrm{C}$ until analysis. 


\subsubsection{Plasma Metabolite Analysis}

Plasma samples were assayed at the University of Rhode Island on a BioTek Powerwave X340 microplate spectrophotometer (Bio-Tek Instruments, Inc., Winooski, Vermont) similar to methods described by Guglielmo et al. 2005. Samples were diluted three-fold with $0.9 \% \mathrm{NaCl}$. Uric acid, triglyceride, and glycerol were measured sequentially by endpoint assay (Wako Diagnostics and

Sigma, St. Louis, Missouri). Beta-hydroxybutyrate was measured by kinetic assay (R-Biopharm, Marshall, Michigan). All samples were run in duplicate unless the coefficient of variation standards were not met, in which case an additional replicate was run.

\subsubsection{Statistical Analysis}

We used a two-sample Welch's t-test to compare plasma metabolites of juvenile grebes (those that hatched that previous summer; $n=16$ ) to adult grebes $(\mathrm{n}=27)$. We used a non-parametric independent two-sample location test (oneway randomization test with 9999 Monte Carlo re-samplings) for two comparisons: (1) plasma metabolites between grebes that were sampled immediately after expiration $(n=8)$ were compared with those live caught $(n=3)$ and (2) resting birds $(n=9)$ were compared with those sampled during daily activity $(\mathrm{n}=11)$. Plasma metabolite data of active grebes were normally distributed after log transformations and then compared among the three locations using an ANOVA and Tukey's post hoc test if ANOVA warranted further testing. We used Pearson's correlation tests for grebe mass and each metabolite. All 
analyses were done in R version 3.0.2. Following Hurlbert and Lombardi (2009, but see also Altman 1991:168), we provide p-values for all our tests so that a more complete evaluation of our interpretation of results is possible. 


\subsection{RESULTS}

Live-caught and recently shot Eared Grebes showed no essential differences in plasma TRIG $(Z=-0.925, p=0.412)$, URIC $(Z=-1.51, p=0.142)$, $\operatorname{BUTY}(Z=-1.10, p=0.282)$, and GLY $(Z=-1.11, p=0.303)$. Likewise, juvenile and adult birds showed no differences in plasma TRIG $\left(\mathrm{t}_{42}=1.225, \mathrm{p}=0.227\right)$, $\operatorname{URIC}\left(\mathrm{t}_{42}=-1.100, \mathrm{p}=0.278\right), \operatorname{BUTY}\left(\mathrm{t}_{42}=0.305, \mathrm{p}=0.762\right)$, and GLY $\left(\mathrm{t}_{42}=-\right.$ $1.171, \mathrm{p}=0.865)$. Thus, we did not distinguish between samples from live-caught and recently shot birds, or juveniles and adults for the remainder of the analyses.

Resting grebes held overnight and sampled at dawn had lower plasma TRIG $(Z=2.075, p=0.016)$ and URIC $(Z=2.149, p=0.026)$, higher plasma BUTY $(Z=-1.762, p=0.055)$, and similar plasma GLY $(Z=0.735, p=0.597$; Fig. 2.2) compared to actively foraging grebes.

Plasma metabolites revealed several important differences among the three areas used by grebes while living and foraging on the water. Plasma TRIG was highest at Salton Sea, lowest at Mono Lake, and intermediate at Great Salt Lake (Table 2.1). TRIG was the only metabolite to show a clear differentiation of Salton Sea to both Mono Lake and Great Salt Lake $\left(\mathrm{F}_{2,41}=4.18, \mathrm{p}=0.022\right.$; Fig. 2.3), which was followed by a Tukey's post hoc test showing no difference between Mono Lake and Great Salt Lake $\left(t_{2}=0.22, p=0.885\right)$. URIC followed the same pattern as TRIG but the differences were small $\left(\mathrm{F}_{2,41}=2.30, \mathrm{p}=0.113\right)$. BUTY and GLY were indistinguishable at all locations $\left(\mathrm{F}_{2,41}=0.39, \mathrm{p}=0.681\right.$; $\mathrm{F}_{2,41}=0.06, \mathrm{p}=0.943$, respectively). 
Body mass of Eared Grebes at Salton Sea $(404.36 \pm 23.63,300-545 \mathrm{~g})$ tended to be higher than at Mono Lake (347.27 $\pm 19.46,230 \mathrm{~g}-540 \mathrm{~g})$ and Great Salt Lake $(372.45 \pm 39.99,320 \mathrm{~g}-435 \mathrm{~g})$, although the substantial variation in body mass at each location meant they were statistically indistinguishable $\left(\mathrm{F}_{2,41}=\right.$ 1.1, $\mathrm{p}=0.346$ ). Body mass of Eared Grebes was positively correlated with plasma TRIG and URIC at both Mono Lake $\left(\mathrm{R}_{\text {TRIG 20 }}=0.70, \mathrm{p}=<0.001 ; \mathrm{R}_{\text {URIC } 20}\right.$ $=0.71, \mathrm{p}<0.001)$ and Great Salt Lake $\left(\mathrm{R}_{\mathrm{TRIG} 9}=0.64, \mathrm{p}=0.032 ; \mathrm{R}_{\mathrm{URIC} 9}=0.70, \mathrm{p}\right.$ $=0.017)$; however, no correlation was found for either metabolite in grebes at Salton Sea $\left(\mathrm{R}_{\mathrm{TRIG} 9}=-0.11, \mathrm{p}=0.740 ; \mathrm{R}_{\mathrm{URIC} 9}=-0.28, \mathrm{p}=0.402 ;\right.$ Figs. 2.4 and 2.5). No correlations were detected at any area between body mass and either BUTY $\left(\mathrm{R}_{\mathrm{ML} 20}=0.03, \mathrm{p}=0.889 ; \mathrm{R}_{\mathrm{GSL} 9}=-0.24, \mathrm{p}=0.480 ; \mathrm{R}_{\mathrm{SS} 9}=-0.19, \mathrm{p}=\right.$ $0.585)$ or GLY $\left(\mathrm{R}_{\mathrm{ML} 20}=0.22, \mathrm{p}=0.326 ; \mathrm{R}_{\mathrm{GSL} 9}=0.02, \mathrm{p}=0.956 ; \mathrm{R}_{\mathrm{SS} 9}=0.28, \mathrm{p}=\right.$ $0.409)$. 
Figure 2.2. Mean $( \pm \mathrm{SE})$ concentrations $(\mathrm{mmol} / \mathrm{L})$ of triglycerides $(\mathrm{TRIG})$, betahydroxybutyrate (BUTY), uric acid (URIC) and glycerol (GLY) for actively staging grebes and resting grebes both at Great Salt Lake (GSL) held overnight. Actively staging grebes are represented by solid black bars and resting grebes are represented by grey bars. Differences between actively staging and resting grebes $(\mathrm{p}<0.05)$ are indicated by an asterisk above metabolite pairs. 


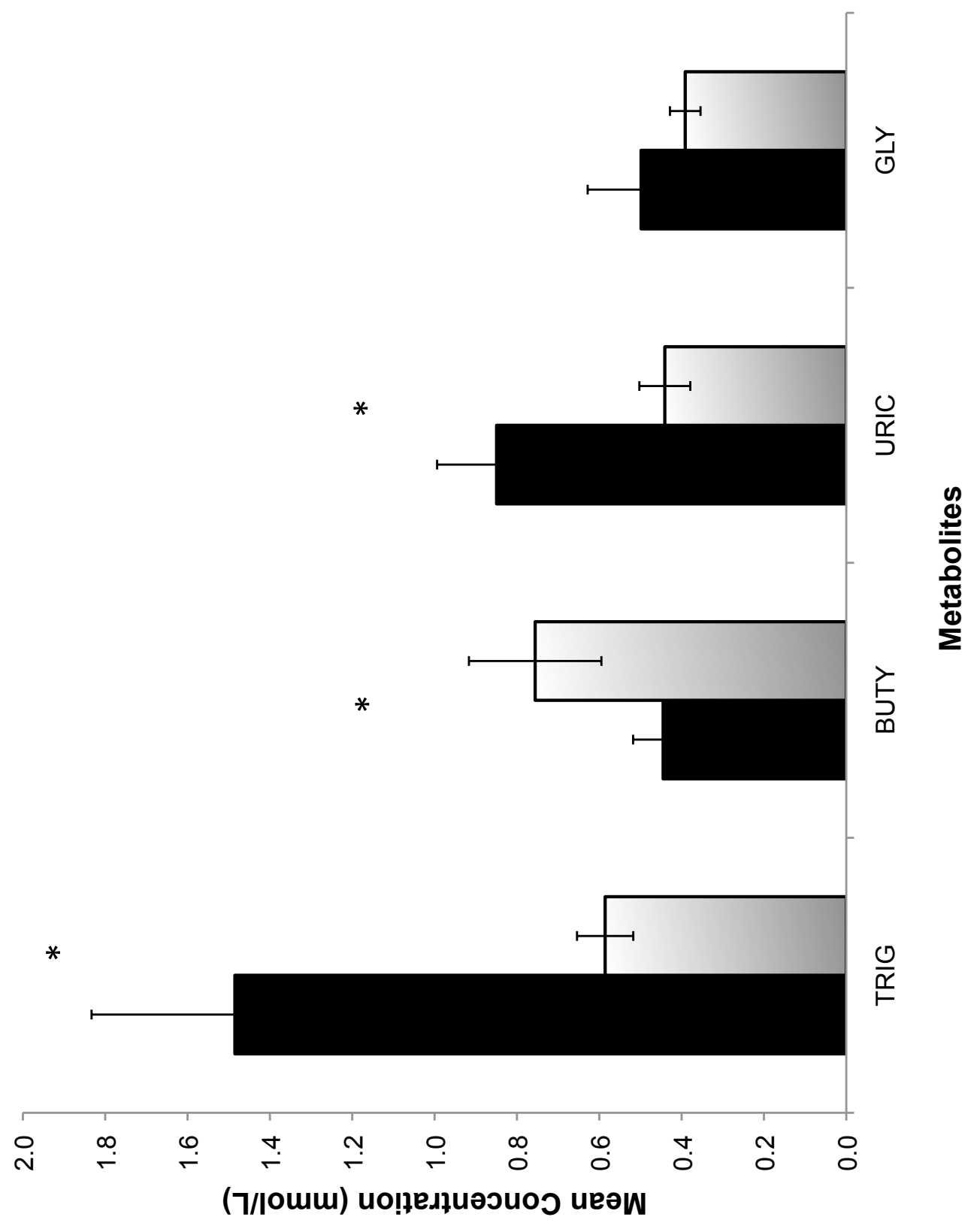


Table 2.1. Eared Grebe plasma metabolite sample sizes (n), means $( \pm \mathrm{SE})$, and p-values of triglyceride (TRIG), uric acid (URIC), betahydroxybutyrate (BUTY), and glycerol (GLY) at Mono Lake, Great Salt Lake, and Salton Sea. 


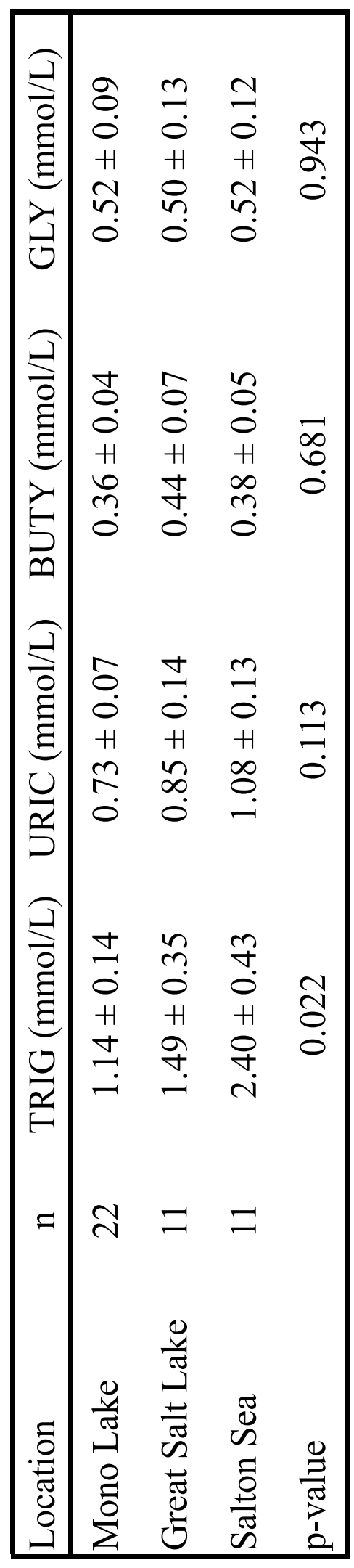


Figure 2.3. Plasma metabolites measured at three non-migratory periods during fall staging at Mono Lake (ML), late-winter staging at Salton Sea (SS), and spring staging at Great Salt Lake (GSL). Differences among sites for a given metabolite are denoted by different letters (A and $\mathrm{B}, \mathrm{p}=0.022)$. Heavy lines within boxes are medians and the boxes represent the interquartile range. 

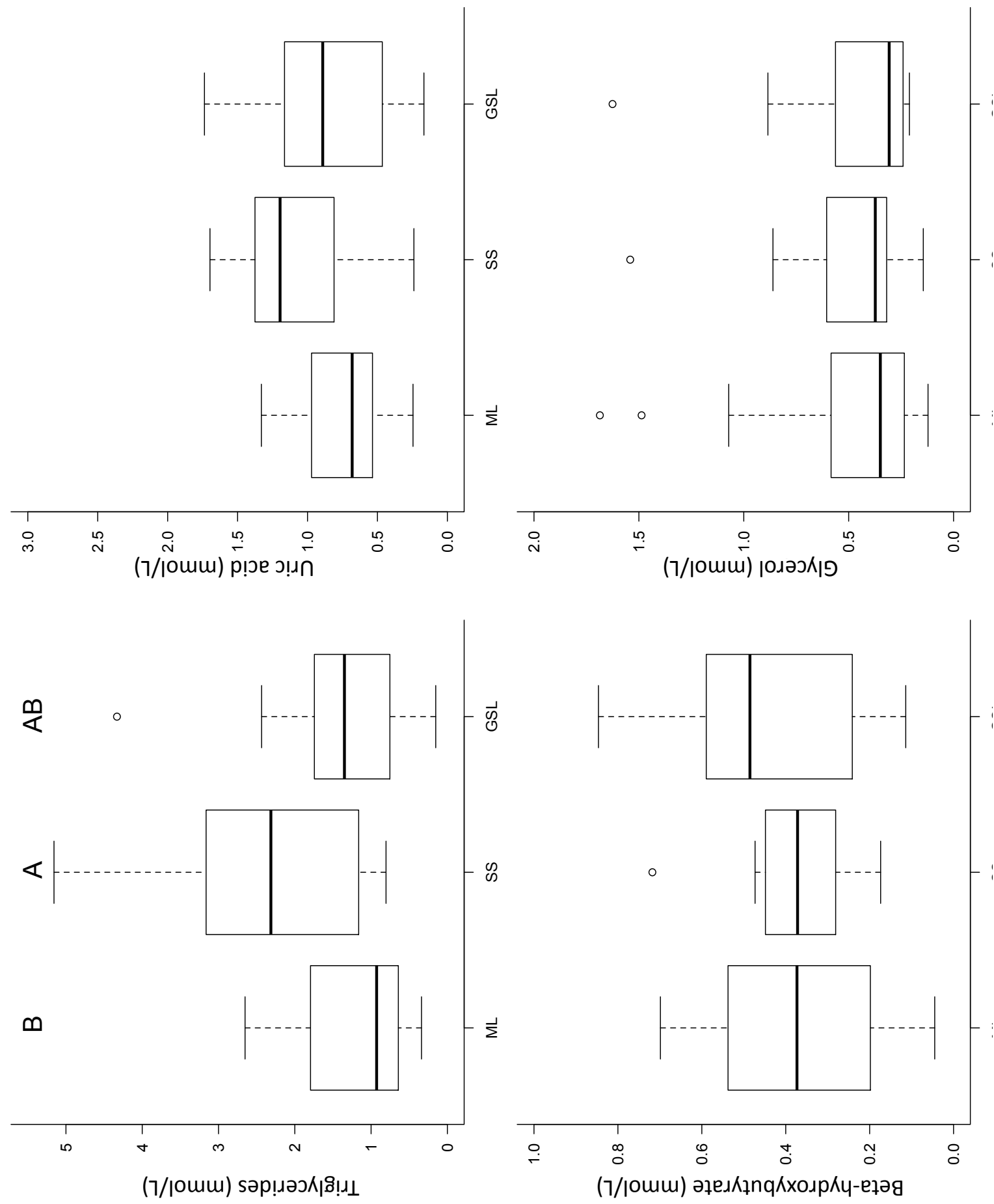
Figure 2.4. Relationship between body mass and triglycerides for Eared Grebes residing at three important sites used while foraging at staging locations or an extended stopover. 

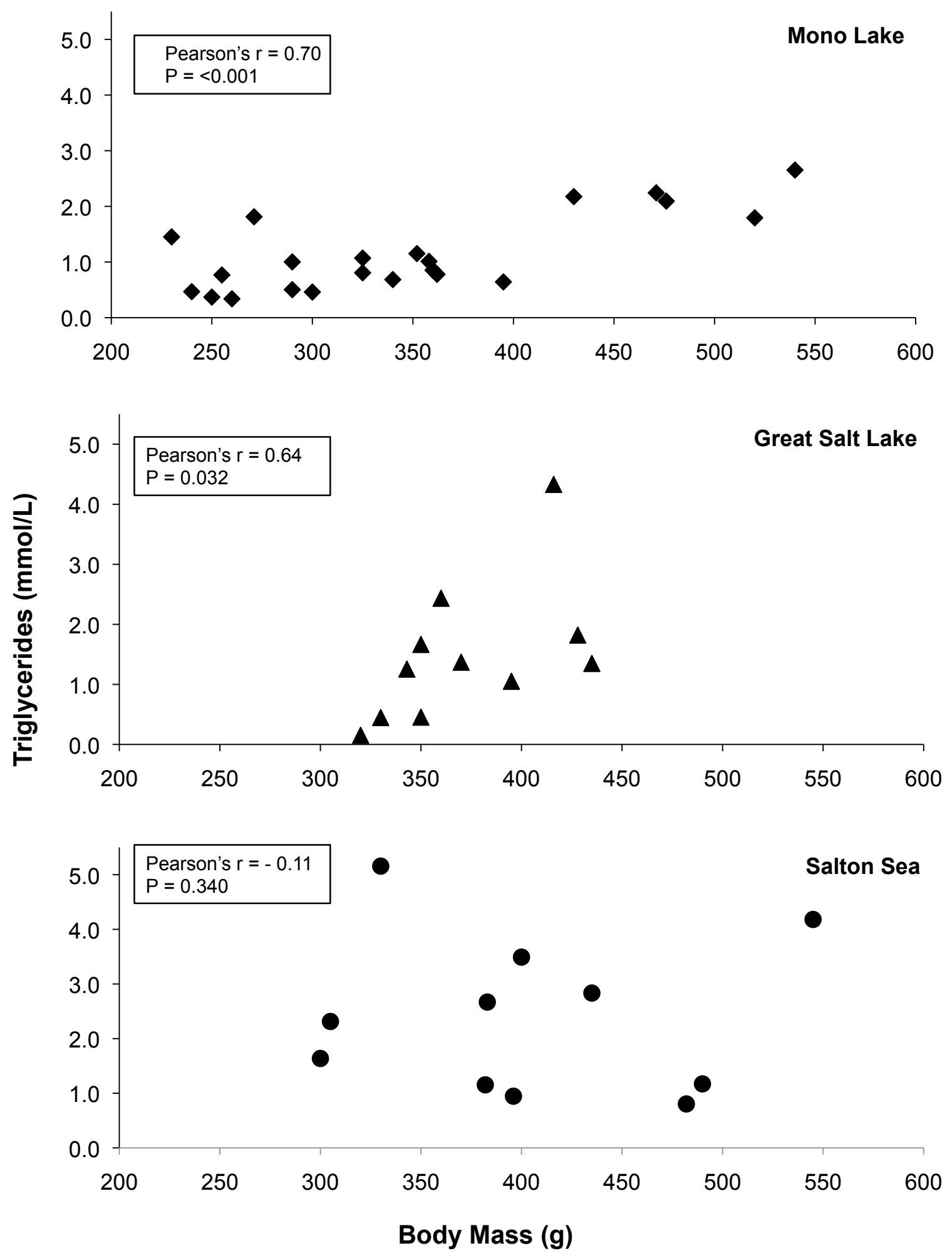
Figure 2.5. Relationship between body mass and uric acid for Eared Grebes residing at three important sites used while foraging at staging locations or an extended stopover. 

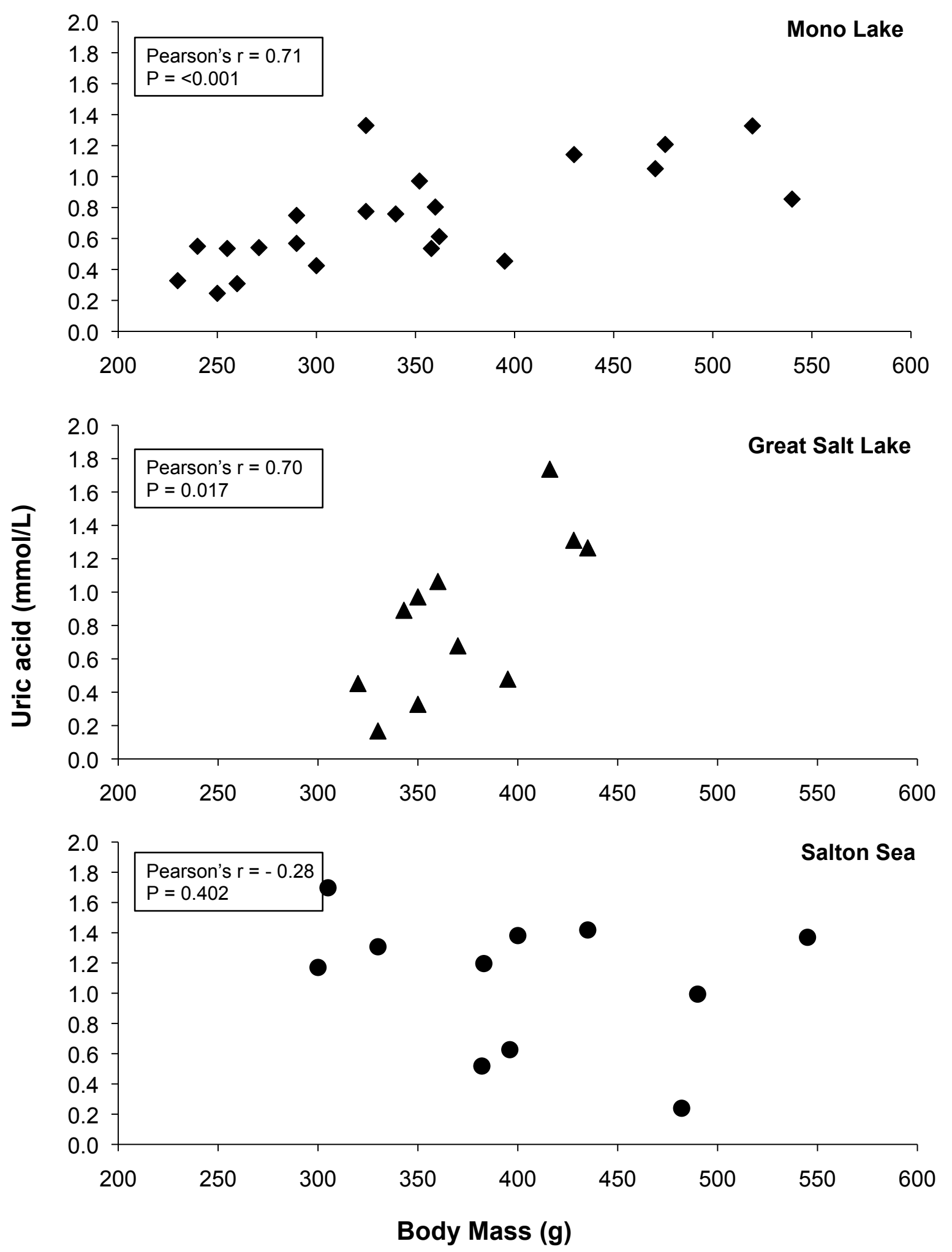


\subsection{DISCUSSION}

Plasma metabolites measured in Eared Grebes during two non-migratory staging periods and a prolonged stopover suggest that the nutritional stores of grebes, and especially their storage of fat, was spatially and temporally dynamic across three commonly used staging and extended stopover areas: Mono Lake, Salton Sea, and Great Salt Lake.

\subsubsection{Resting and Active Grebes at Great Salt Lake}

Comparing active and overnight resting grebes from Great Salt Lake, plasma metabolite values suggested differences in nutritional state between the two groups. Specifically, plasma TRIG in active Eared Grebes was more than two times higher than in resting grebes while the opposite was found for plasma BUTY probably because the resting birds were utilizing stored fat for energy. TRIG, URIC and BUTY levels in resting grebes were comparable to those found in other studies of fasting birds. Plasma metabolites in our resting grebes were similar to those of Bar-tailed Godwits (Limosa lapponica) rested for $5 \mathrm{~h}$, except for TRIG levels, which were higher in the godwits (Table 2.1). Grebes in this study were rested three times longer than the Bar-tailed Godwits providing more time for TRIG to disappear from the blood. It is uncertain how much time it takes for metabolites to return to resting baseline, however in homing pigeons it takes 30 min to begin showing a return to baseline (Schwilch et al. 1996). Resting grebes had lower URIC levels in their plasma, indicating lower protein catabolism. This suggests that resting grebes utilized fat stores before protein stores compared with active grebes or that protein is used minimally while at rest. 
This preference for utilizing fat before protein stores has been documented for non-avian species (Felig 1979) as well as for penguins. It was first described in long-fasting penguins by Cherel and Le Maho (1988) who showed that starving penguins only utilized protein in the last stage of starvation after fat was largely depleted. The lack of elevated plasma URIC in the Great Salt Lake grebes illustrates one difference between overnight fasting and long-term fasting. However, the lack of an elevated URIC and the presence of an elevated BUTY in overnight resting grebes does confirm the order of nutrient store use found by Cherel and Le Maho (1988). These prior studies combined with the present study indicating the order of nutritional stores used (fat stores used before protein stores) for resting highlights the same order of nutritional stores used in migrating birds.

\subsubsection{Staging at Mono Lake and Great Salt Lake}

Eared Grebes show certain ecological similarities at staging areas that are reflected in some plasma metabolites. Fall and spring staging groups tend to be somewhat synchronized, arriving at their lakes over a fairly short period and departing together. They also show a relatively synchronized increase in mass during their staging sojourns (Jehl 1988). During both fall staging at Mono Lake and spring staging at Great Salt Lake, there was a correlation between TRIG and body mass that was not apparent during an extended stopover. TRIG levels were also similar in both locations. During fall staging at Mono Lake, grebes gain weight and put on fat as long as their food remains (Jehl 1988, 2007). The correlation between TRIG, an indicator of fat deposition, and body mass in grebes 
at Mono Lake and Great Salt Lake (Fig. 2.4) suggest that staging is an important fat-storing period of the annual cycle. Large amounts of fat storing contributes late in staging to obese grebes that are too big to fly and must actually lose both mass and fat prior to departure once their food disappears (Jehl 1988, 1997; Jehl et al. 2003). The positive relationship between TRIG and body mass found in grebes at these staging locations may be related to heavier birds having more fat and so higher circulating levels of TRIG (Smith 2007; Smith and McWilliams 2009), or heavier birds fattening at higher rates (Guglielmo et al. 2005; Cerasale and Guglielmo 2006). Food abundance at Mono Lake may have decreased across sampling years, as indicated by the reduction in TRIG levels in October 2012 and 2013 compared to 2011, and this may explain earlier departures (October) of grebes from Mono Lake since 2012 (J.R. Jehl, pers. comm.; A. Yoshida, pers. obs. 2013; S. San Francisco and H.I. Ellis, pers. obs. 2014). The shift to an earlier departure from Mono Lake is dramatic because fall staging birds typically leave Mono Lake in very large flocks over a short time during late fall or early winter (Jehl and Johansson 2002; Jehl and Henry 2010).

Grebes at Great Salt Lake in the spring are also synchronized, but not to the same extent as they are in the fall there or at Mono Lake. In the spring, Great Salt Lake (mid-April through June) is known to be where most grebes molt into their breeding plumage, as well as court and establish mating pairs (Jehl 1988; Cullen et al. 1999). At Great Salt Lake, grebes feed and accumulate fat stores just as they do at Mono Lake, but fatty acid signatures suggest grebes at Great Salt Lake may be less synchronized in their arrival and resumption of fattening than 
grebes at fall staging areas. Gafney (2009) found that the difference in diet, pile worms and brine shrimp at Salton Sea and Great Salt Lake respectively, resulted in different fatty acid signatures found in grebes caught at Great Salt Lake, which supported the variation and timeline of grebes stopping at Salton Sea. This variation was not hat grebes without the Salton Sea signature were not stopping at Salton Sea, but instead supports the timeline that by May, the Salton Sea fatty acid signature had already been metabolized out of the grebes' system. The relatively weak correlation of TRIG $(r=0.64, p=0.032)$ with body mass at Great Salt Lake in spring compared to Mono Lake in fall $(\mathrm{r}=0.70, \mathrm{p}=<0.001)$ suggest synchronization of arrival and departure is not as tight as seen at Mono Lake.

Unlike TRIG, we detected no differences among sites in URIC indicating protein breakdown does not shift heavily across non-migratory periods (Fig. 2.3). Plasma URIC in Eared Grebes during staging at Mono Lake and Great Salt Lake did not differ $\left(F_{2,41}=2.30, p=0.113\right.$, Fig. 2.3 $)$. These similarities suggest protein breakdown does not drastically change during staging periods of the annual cycle. Eared Grebes at Great Salt Lake in the spring were similar to those at Mono Lake in the fall in that their plasma URIC, like TRIG, was positively correlated to body mass, even though body mass range at Great Salt Lake was smaller than at Mono Lake (Fig. 2.5). Increased plasma URIC during such feeding phases may in part be due to breakdown of dietary protein to satisfy energy requirements such as protein catabolism to build fat stores (Cherel and Le Maho 1988; Jenni-Eiermann and Jenni 1991). 
Beta-hydroxybutyrate and glycerol levels in grebes residing at Mono Lake were nearly identical to those in grebes at Great Salt Lake, although plasma BUTY was more variable in grebes at Great Salt Lake (Fig. 2.3). Higher variability in plasma BUTY at Great Salt Lake may be due to increased energy allocation to courtship displays which may differ in extent between individuals (Vehrencamp et al. 1989). It is possible that courtship displays of grebes, which involve lifting themselves out of water can be energetically expensive although this has not been measured. These metabolites increase in concentration with fat catabolism and Eared Grebes, even when food availability was reduced, were observed feeding to some extent during all sampling periods. Some studies on passerines and shorebirds found a negative relationship between TRIG and betahydroxybutyrate at refueling sites (Guglielmo et al. 2002, 2005; Liu and Swanson 2014) suggesting those birds were either depositing fat or using it. No such negative correlation was found in Eared Grebes during daylight activities at either staging location, though it was found at Great Salt Lake when comparing active and resting grebes.

Plasma glycerol in Eared Grebes residing at Great Salt Lake and Mono Lake remained unchanged. The stability of glycerol (Table 2.1 and Fig. 2.3) of these birds even when comparing resting and active grebes (see below) suggests that glycerol is highly regulated in Eared Grebes. Though it is traditionally an indicator of fat breakdown (Cherel et al. 1988), circulating glycerol may play an additional role in fat metabolism resulting in a U-shaped relationship with TRIG (Guglielmo 2005) in some studies (Landys et al. 2005; Acevado Seaman et al. 
2006). No such relationship was found in this study, however. It would be interesting to look at glycerol in a future study of Eared Grebes plasma metabolites while migrating. In general, the overall nutritional state of grebes during staging at Mono Lake and spring staging at Great Salt Lake primarily involved fat storage with some protein breakdown.

\subsubsection{Extended Stopover at Salton Sea}

The highest TRIG values were found at Salton Sea. This indicates Eared Grebes were fattening at a higher rate during this extended stopover location on the vernal migration route than when they were at Mono Lake in the fall or Great Salt Lake in the spring. Increased fat deposition is often found at migratory stopover locations in other species where they refuel and rest for the next leg of migration (Landys et al. 2004; Williams et al. 2007); however, Salton Sea is not a traditional refueling stop. During the vernal migration, grebes arrive at the Salton Sea from the Gulf of California wintering area over an extended period of time suggesting that individuals are not yet tightly synchronized in their movements. Their arrival and departure is often in multiple waves, unlike the situation at Mono Lake and Great Salt Lake (Jehl and McKernan 2002). Waves of arriving birds means that from late-February through mid to late-April, there are grebes in various stages of fattening at Salton Sea. This is supported by the complete lack of correlation between body mass and TRIG and URIC (Fig. 2.4, Fig. 2.5) as well as the impressive range in plasma TRIG values in grebes at Salton Sea (Fig. 2.3). Similarity of plasma URIC between grebes at Mono Lake and Great Salt Lake, as well as the positive correlation between URIC and body mass supports arrival and 
departure synchrony at these sites. This correlation between plasma URIC and body mass seen at the staging areas, but not at Salton Sea may occur because Eared Grebes were arriving in waves at Salton Sea so that individuals sampled at a given time varied in nutritional state. Even though grebes are at Salton Sea for a shorter period of time than at Mono Lake and Great Salt Lake, they still go through the same changes in body composition upon arrival and again before departure and exhibit the same flightlessness while on the lake (Jehl 1997).

Beta-hydroxybutyrate and glycerol values at Salton Sea were very similar to staging locations at Mono Lake and Great Salt Lake suggesting fat catabolism throughout the non-migratory periods of the annual cycle remain relatively the same and highly regulated.

It is clear from the elevation of TRIG and lack of body mass correlation with either TRIG or URIC that Salton Sea is different from Eared Grebe staging sites at Mono Lake and Great Salt Lake. This extended stopover serves as period for grebes to build nutritional stores to successfully arrive at spring staging locations to feed and prepare for the breeding season.

\subsubsection{Comparisons to Other Species During Migratory Periods}

Plasma metabolites in grebes at three areas during the non-migratory period can be compared to plasma metabolites in other species of migratory birds sampled during migration and breeding periods of the annual cycle. For example, breeding Wood Thrushes (Hylocichla mustelina) had similar plasma metabolite levels (Done et al. 2011) as active Eared Grebes (Table 2.2). Similarities in both TRIG and BUTY suggest both fat deposition and catabolism during a non- 
migratory period do not heavily vary. This also reflects the lower expense of activities (reproductive or not) during non-migratory periods and the lower requirement for storing fat compared to migrants. For example, TRIG levels in migrating and refueling birds were on average higher than active Eared Grebes at Mono Lake and Great Salt Lake during the non-migration period (Table 2.2). High TRIG values during migration have been found in passerines (JenniEiermann and Jenni 1991), which can come from free-fatty acids in the liver being re-esterified into TRIG during flight (Havel 1987; Wolfe et al. 1990). Fat deposition at refueling sites, especially in Bar-tailed Godwits, was higher than TRIG levels at all three locations studied here for Eared Grebes, however, grebes at Salton Sea had the closest TRIG values at about half of those for the godwits. This further supports refueling sites' primary role of rapid fat uptake and Salton Sea's role as an extended stopover for Eared Grebes. In comparison to TRIG values at refueling stops in other studies, our study suggests fat deposition during staging is not elevated to the extent found during refueling periods. Higher TRIG at refueling stops underscores Salton Sea as more than simply a long refueling stop even though TRIG levels at Salton Sea were highest among our three locations.

In contrast, plasma URIC of Eared Grebes during the non-migratory period was more similar to birds actively migrating or refueling. Values for refueling Bar-tailed Godwits were exceptional (Table 2.2) likely because these godwits were sampled immediately after a two-day flight (Landys et al. 2005) follows the same general trend shown by TRIG: protein is used most heavily 
during refueling, but is also required for flight. It is found to be higher during the first 20 min of flight, and it also increases with flight duration (Gerson and Guglielmo 2013). These URIC level similarities suggest a relatively constant use of protein in most activities. Migration strategy and diet could account for some of the differences found in the godwits. It is possible that the godwits show an elevated URIC level during migration because they had depleted their fat stores from their exceptionally long flight duration.

A comparison of the plasma metabolites of Eared Grebes during the nonmigratory period to those of Wood Thrushes during the breeding season further support the importance of the non-migratory period for nutrient acquisition. Although these two species are in differences in size and taxonomic groups they show similar TRIG and BUTY values (Table 2.2). Whether energy is needed for swimming and foraging for the grebes or for reproductive effort seen in Wood Thrushes, the nutrients acquired during that time is important for a successful migration. Done et al. (2011) found the physiological effects from reproductive effort during the breeding season can have an effect on the following fall migration. Both the study on Wood Thrushes and this one on Eared Grebes highlight the importance in understanding current plasma metabolites studies, which focus primarily on the migratory period. A complete story of metabolite use year round is essential for a comprehensive understanding of its separate parts. 
Table 2.2. Plasma triglycerides (TRIG), beta-hydroxybutyrate (BUTY), uric acid (URIC) and glycerol (GLY) expressed as average $\mathrm{mmol} / \mathrm{L} \pm \mathrm{SE}$ during various periods of the annual cycle for various species or groups of species of migratory birds. Resting and actively swimming Eared Grebes during the non-migratory period are also shown. In the table, the term "Migrants" refers to birds caught upon arrival at refueling sites at the end of a migration leg, and "Refueling" refers to birds caught hours to days into a stopover site. 


\begin{tabular}{|c|c|c|c|c|c|c|c|}
\hline $\begin{array}{c}\text { Period of } \\
\text { Annual Cycle }\end{array}$ & Groups or Species & $\begin{array}{c}\text { \# of } \\
\text { species }\end{array}$ & TRIG & BUTY & URIC & GLY & Source \\
\hline Migration & Passerines & 10 & $2.18 \pm 0.24$ & $1.84 \pm 0.14$ & $0.75 \pm 0.08$ & $0.77 \pm 0.05$ & $\begin{array}{c}\text { Jenni-Eiermann and } \\
\text { Jenni 1991, Gannes } \\
2001 \\
\end{array}$ \\
\hline Migration & $\begin{array}{l}\text { Western Sandpiper } \\
\text { (Calidris mauri) }\end{array}$ & 1 & $2.03 \pm 0.15$ & $0.66 \pm 0.13$ & - & $0.29 \pm 0.01$ & Guglielmo et al. 2002 \\
\hline Migration & $\begin{array}{l}\text { Bar-tailed Godwit } \\
\text { (Limosa lapponica) }\end{array}$ & 1 & $1.20 \pm 0.20$ & $0.71 \pm 0.15$ & $1.25 \pm 0.22$ & $0.85 \pm 0.65$ & Landys et al. 2005 \\
\hline Refueling & Passerines & 15 & $1.90 \pm 0.19$ & $1.38 \pm 0.17^{\mathrm{a}}$ & $0.61 \pm 0.09^{b}$ & $0.77 \pm 0.12^{\mathrm{c}}$ & $\begin{array}{c}\text { Guglielmo et al. 2005, } \\
\text { Ogden et al. 2013, } \\
\text { Smith and } \\
\text { McWilliams } 2010\end{array}$ \\
\hline Refueling & Shorebirds & 4 & $2.06 \pm 0.26$ & $0.60 \pm 0.12^{\mathrm{d}}$ & - & $0.76 \pm 0.03$ & $\begin{array}{l}\text { Seaman et al. 2006, } \\
\text { Thomas and Swanson } \\
2013\end{array}$ \\
\hline Refueling & $\begin{array}{l}\text { Bar-tailed Godwit } \\
\text { (Limosa lapponica) }\end{array}$ & 1 & $4.60 \pm 0.28$ & $0.15 \pm 0.03$ & $2.20 \pm 0.20$ & $0.55 \pm 0.08$ & Landys et al. 2005 \\
\hline $\begin{array}{l}\text { Extended stop } \\
\text { at Salton Sea } \\
\text { Eared Grebe }\end{array}$ & (Podiceps nigricollis) & 1 & $2.40 \pm 0.43$ & $0.38 \pm 0.05$ & $1.08 \pm 0.13$ & $0.52 \pm 0.12$ & Present Study \\
\hline $\begin{array}{l}\text { Non-migration: } \\
\text { swimming } \\
\text { Eared Grebe }\end{array}$ & (Podiceps nigricollis) & 1 & $1.26 \pm 0.22$ & $0.39 \pm 0.07$ & $0.77 \pm 0.13$ & $0.51 \pm 0.09$ & Present study \\
\hline $\begin{array}{l}\text { Non-migration: } \\
\text { breeding }\end{array}$ & $\begin{array}{l}\text { Wood Thrush } \\
\text { (Hylocichla } \\
\text { mustelina) }\end{array}$ & 1 & $1.05 \pm 0.05$ & $0.33 \pm 0.01$ & - & $0.36 \pm 0.07$ & Done et al. 2011 \\
\hline $\begin{array}{l}\text { Resting } \\
\text { overnight }\end{array}$ & $\begin{array}{l}\text { Bar-tailed Godwit } \\
\text { (Limosa lapponica) }\end{array}$ & 1 & $1.00 \pm 0.01$ & $0.70 \pm 0.05$ & $0.30 \pm 0.03$ & $0.30 \pm 0.20$ & Landys et al. 2005 \\
\hline $\begin{array}{l}\text { Resting } \\
\text { overnight }\end{array}$ & $\begin{array}{c}\text { Eared Grebe } \\
\text { (Podiceps nigricollis) }\end{array}$ & 1 & $0.59 \pm 0.07$ & $0.76 \pm 0.16$ & $0.44 \pm 0.06$ & $0.39 \pm 0.04$ & Present study \\
\hline
\end{tabular}

$$
\begin{aligned}
& \mathrm{a}=12 \text { species } \\
& \mathrm{b}=8 \text { species } \\
& \mathrm{c}=10 \text { species } \\
& \mathrm{d}=3 \text { species }
\end{aligned}
$$




\section{CHAPTER 3: SUMMARY}

1. Eared Grebes are a migratory waterbird whose annual migration includes long staging periods at Mono Lake and Great Salt Lake and an extended stopover at Salton Sea. When they are not flying, they are foraging while swimming and diving. While on the lakes, their bodies undergo rapid changes in body composition with digestive viscera hypertrophying while they build up nutritional stores and can more than double in weight. These changes include breast muscle atrophy so extreme they become flightless. Such drastic differences in body composition between a flying grebe and those at staging and extended stopover areas suggest changes in how nutritional stores are used during these times.

2. In this study I examined the nutritional state of Eared Grebes as defined by their plasma metabolites (TRIG, BUTY, URIC and GLY) and inferred their nutritional stores during two staging and one extended stopover period of their annual cycle. A baseline was first established to provide a context for plasma metabolites of active grebes by comparing active and completely resting nonmigratory Eared Grebes. I found that grebes at rest had higher BUTY (fat breakdown), but lower TRIG (fat deposition) and URIC (protein breakdown) than active grebes at the three study locations. There was no change in glycerol between both groups of grebes.

3. When plasma metabolites were examined from grebes at Mono Lake, Great Salt Lake, and Salton Sea, I found that TRIG most clearly defined nutritional state between extended stopover (Salton Sea) and staging locations (Mono 
Lake and Great Salt Lake). Grebes at Salton Sea had the highest TRIG values meaning they deposited fat at a higher rate, yet they had no correlation with body mass despite having and overall higher body mass. This was unlike what staging grebes at Mono Lake and Great Salt Lake showed where TRIG values were lower, but had a positive correlation between TRIG and body mass. Additionally, protein breakdown indicated by URIC was also highest at Salton Sea and like TRIG, displayed no correlation to body mass. The differences found at Salton Sea compared to the more similar locations of Mono Lake and Great Salt Lake emphasize the importance of the extended stopover at Salton Sea to build nutritional stores and fluctuation of nutritional state during nonmigratory periods.

4. Lastly, this study allowed a comparison of plasma metabolites between nonmigratory and migratory periods of flight and refueling stops. This comparison helps provide us with a context with which we can better interpret existing studies on nutritional state of migrating birds. Most notable is that this study suggests the importance of the non-migratory periods for nutrient storage and fat deposition throughout the annual cycle as shown by TRIG. The focus here on a waterbird species contributes to the growing understanding of changes in nutritional state of all migratory birds, and not on passerines where much of the previous literature has focused.

5. A more comprehensive understanding of energy use and nutritional state in Eared Grebes can be accomplished in future work by creating an annual profile of fuel use. This would include plasma metabolite measurements 
during all periods of the Eared Grebes annuals cycle including the breeding and wintering seasons for non-migratory periods. Lastly, metabolite measurements during flight and when they sometimes land in smaller bodies of water for the day, but do not feed would complete a profile of nutritional use for a migratory waterbird. 


\section{LITERATURE CITED}

Acevado Seaman, D. A., Guglielmo, C. G., Elner, R. W. and Williams, T. D. 2006. Landscape-scale physiology: site differences in refueling rates indicated by plasma metabolite analysis in free-living migratory sandpipers. Auk 123: 563-574.

Altman, D. G. 1991. Some common problems in medical research. Practical statistics for medical research 1: 396-403.

Anderson, T.W., Tiffany, M. and Hurlbert, S. H. 2007. Stratification, sulfide, worms, and decline of the Eared Grebe (Podiceps nigricollis) at the Salton Sea, California. Lake and Reservoir Management 23: 500-517.

Anteau, M. J. and Afton, A. D. 2009. Lipid reserves of lesser scaup (Aythya affinis) migrating across a large landscape are consistent with the "spring condition" hypothesis. Auk 126: 873-883.

Anteau, M. J. and Afton, A. D. 2011. Lipid catabolism of invertebrate predator indicates widespread wetland ecosystem degradation. PLoS ONE 6: e16029.

Bergen, A. 2003. Enzyme activities associated with changes in body composition in Eared Grebes during fall staging. Thesis, University of San Diego. San Diego, California, USA.

Caudell, J. N. and Conover, M. R. 2006. Behavioral and physiological responses of eared grebes (Podiceps nigricollis) to variations in brine shrimp (Artemia franciscana) densitites. Western North American Naturalist 66: $12-22$. 
Caudell, J. N. and Conover, M. R. 2007. Drive-by netting: a technique for capturing grebes and other diving waterfowl. Human-Wildlife Conflicts 1: 49-52.

Cerasale, D. J. and Guglielmo, C. G. 2006. Dietary effects on prediction of body mass changes in birds by plasma metabolites. Auk 123: 836-846.

Cherel, Y. and Le Maho, Y. 1988. Changes in body mass and plasma metabolites during short-term fasting in the king penguin. Condor 90: 257258.

Cherel, Y., Robin, J. P., Walch, O., Karmann, H., Netchitailo, P. and Le Maho, Y. 1988. Fasting in king penguin I. Hormonal and metabolic changes during breeding. Am. J Physiol. Regulatory Integrative Comp. Physiol. 254: 170177.

Conover, M. R. and Caudell, J. N. 2009. Energy budgets for Eared Grebes on the Great Salt Lake and implications for harvest of brine shrimp. J. Wildlife Management 73: 1134-1139.

Cullen, S. A., Jehl, J. R., Jr. and Nuechterlein, G. L. 1999. Eared Grebe (Podiceps nigricollis). In Poole, A. \& F. Gill (eds), The birds of North America. Number 433 (A. Poole and F. Gill, eds.). The Birds of North America, Inc., Philadelphia, PA .

Dietz, M. W., Jenni-Eiermann, S. and Piersma, T. 2009. The use of plasma metabolites to predict weekly body-mass change in red knots. Condor 111: 88-99. 
Done, T., Gow, E. A. and Stutchbury, B. J. 2011. Corticosterone stress response and plasma metabolite levels during breeding and molt in a free-living migratory songbird, the wood thrush (Hylocichla mustelina). Gener. Comp. Endocrin. 171: 176-182.

Elia, M., Zed, C., Neale, G. and Livesey, G. 1987. The energy cost of triglyceride-fatty acid recycling in non-obese subjects after an overnight fast and four days of starvation. Metabolism 36: 251-255.

Ellis, H. I. 1994. Summer activity cost of eared grebes at Mono Lake. HubbsSeaWorld Research Institute Technical Report No. 94-253.

Ellis, H. I. and Jehl, J. R., Jr. 2003. Temperature regulation and the constraints of climate in the Eared Grebe. Waterbirds 26: 275-279.

Felig, P. 1979. Starvation. In Endocrinology. Edited by L.J. De Groot et al. Grune and Stratton, New York, pp. 1927-1940.

Gafney, J. M. 2009. Tracking Eared Grebe (Podiceps nigricollis) migration using fatty acid signature analysis. Thesis, University of San Diego, San Diego, California, USA.

Gannes, L. Z. 2001. Comparative fuel use of migrating passerines: effects of fat stores, migration distance and diet. Auk 118: 665-667.

Gannes, L.Z. 2002. Mass change patterns of blackcaps refueling during spring migration: evidence for physiological limitations to food assimilation. Condor 104: 231-239.

Gaunt, A. S., Hikida, R. S., Jehl, J. R., Jr. and Fenbert, L. 1990. Rapid atrophy and hypertrophy of an avian flight muscle. Auk 107: 649-659. 
Gerson, A.R. and Guglielmo, C.G. 2013. Energetics and metabolite profiles during early flight in American robins (Turdus migratorius). J.Comp. Physiol. B 183: 983-991.

Gill, R. E., Piersma T., Hufford, G., Servranckx, R. and Riegen, A. 2005. Crossing the ultimate ecological barrier: evidence for an $11000 \mathrm{~km}$-long nonstop flight from Alaska to New Zealand and Eastern Australia by Bartailed Godwits. Condor 107: 1-20.

Giudici, A., Navarro, J., Juste, C. and González-Solís, J. 2010. Physiological ecology of breeders and sabbaticals in a pelagic seabird. J. Experim. Marine Biol. and Ecol. 389: 13-17.

Goldstein, D. L. 1990. Energetics of activity and free living in birds. Stud. Avian Biol. 13: 423-426.

Guglielmo, C. G., O'Hara, P. D. and Williams, T. D. 2002. Extrinsic and intrinsic sources of variation in plasma lipid metabolites of free-living Western Sandpipers (Calidris mauri). Auk 119: 437-445.

Guglielmo, C. G., Cerasale, D. J. and Eldermire, C. 2005. A field validation of plasma metabolite profiling to assess refueling performance of migratory birds. Physiol. Biochem. Zool. 78: 116-125.

Havel, R.J. 1987. Lipid transport function of lipoproteins in blood plasma. Am. J. Physiol. 253: E1-E5.

Hurlbert, S. H. and Lombardi, C. M. 2009. Final collapse of Neyman-Pearson decision theoretic framework and rise of the new Fisherian. Ann. Zool. Fennici 46: 311-349. 
Hurley, B. F., Nemeth, P. M., Martin III, W. H., Hagberg, J. M. Dalsky, G. P. and Holloszy, J. O. 1986. Muscle triglyceride utilization during exercise: effect of training. J. Appl. Physiol. 60: 562-567.

Jehl, J. R., Jr. 1988. Biology of the Eared Grebe and Wilson's pharalope in the nonbreeding season: study of adaptations to saline lakes. Stud. Avian Biol. $12, \mathrm{p} 74$.

Jehl, J. R., Jr. 1993. Observations on the fall migration of Eared Grebes, based on evidence from a mass downing in Utah. Condor 95: 470-473.

Jehl, J. R., Jr. 1997. Cyclical changes in body composition in the annual cycle and migration of the Eared Grebe, Podiceps nigricollis. J. Avian Biol. 28: 132142.

Jehl, J. R., Jr. 2007. Why do Eared Grebes leave hypersaline lakes in autumn? Waterbirds 30: 112-115.

Jehl, J. R., Jr. and Henry, A. H. 2010. The postbreeding migration of Eared Grebes. Wilson J. Ornithol. 122: 217-227.

Jehl, J. R., Jr., Henry, A. H. and Bond, S. I. 1999. Flying the gantlet: population characteristics, sampling bias, and migration routes of Eared Grebes downed in the Utah desert. Auk 116: 178-183.

Jehl, J. R., Jr., Henry, A. H. and Ellis, H. I. 2003. Optimizing migration in a reluctant and inefficient flier: the Eared Grebe. Pp. 199-209 in Avian Migration (P. Berthold, E. Gwinner, and E. Sonnenschein, eds.). SpringerVerlag, Berlin.

Jehl, J. R., Jr. and Johansson, C. 2002. The autumnal migration of Eared Grebes 
through southwestern Wyoming: a key to assessing the size of the North American population. Western North American Naturalist 62: 335-340.

Jehl, J. R., Jr. and McKernan, R. 2002. Biology and migration of Eared Grebes at the Salton Sea. Hydrobiologia 473: 245-253.

Jellison, R. and Melack, J. M. 1993 Meromixis in hypersaline Mono Lake, California. 1 Stratification and vertical mixing during the onset, persistence and breakdown of meromixis. Limnol. Oceanogr. 38: 10081019.

Jenni, L. and Jenni-Eiermann, S. 1998. Fuel supply and metabolic constraints in migrating birds. J. Avian Biol. 29: 521-528.

Jenni, L. and Schwilch, R. 2001. Plasma metabolite levels indicate change in body mass in reed warblers Acrocephalus scirpaceus. Avian Science 1: $55-65$.

Jenni-Eiermann, S. and Jenni, L. 1991. Metabolic responses to flight and fasting in night- migrating passerines. J. Comp. Physiol. B 161: 465-474.

Jenni-Eiermann, S. and Jenni, L. 1994. Plasma metabolite levels predict individual body-mass changes in a small long-distance migrant, the garden warbler. Auk 111: 888-899.

Jenni-Eiermann, S., and Jenni, L. 1996. Metabolic differences between the postbreeding, moulting and migratory periods in feeding and fasting passerine birds. Functional Ecology 10: 62-72. 
Jenni-Eiermann, S., Jenni, L., Kvist, A., Lindstrom, A. and Piersma, T. 2001. Fuel use and metabolic response to endurance exercise: a windtunnel study of a long-distance migrant shorebird. J. Exp. Biol. 205: 2453- 2460.

Jenni-Eiermann, S., Jenni, L. and Piersma, T. 2002. Plasma metabolites reflect seasonally changing metabolic processes in a long-distance migrant shorebird (Calidris canutus). Zool. 105: 239-246).

Klaassen, M. 1996. Metabolic constraints on long-distance migration in birds. J. Exp. Biol. 199: 57-64.

Klaassen, M., Kvist, A. and Lindstrom, A. 2000. Flight costs and fuel composition of a bird migrating in a wind tunnel. Condor 102: 444-451.

Landys, M. M., Ramenofsky, M., Guglielmo, C. G. and Wingfield, J. C. 2004. The low-affinity glucocorticoid receptor regulates feeding and lipid breakdown in the migratory Gambel's white-crowned sparrow Zonotrichia leucophrys gambelii. J. Exp. Biol. 2007: 143-154.

Landys, M. M., Piersma, T., Guglielmo, C. G., Jukema, J., Ramenofsky, M. and Wingfield, J. C. 2005. Metabolic profile of long-distance migratory flight and stopover in a shorebird. Proc. R. Soc. B 272: 295-302.

Lall, U. and Mann, M. 1995. The Great Salt Lake: A barometer of low-frequency climatic variability, Water Resour. Res., 31: 2503-2515.

Lindgård, K., Stokkan, K. A., Le Maho, Y. and Groscolas, R. 1992. Protein utilization during starvation in fat and lean Svalbard ptarmigan (Lagopus mutus hyperboreus). J. Comp. Physiol. B 162: 607-613. 
Lindström A. and Piersma, T. 1993. Mass change in migrating birds: evidence for fat and protein storage re-examined. Ibis 135: 70-78.

Liu, M. and Swanson D.L. 2014. Physiological evidence that anthropogenic woodlots can substitute for native riparian woodlands as stopover habitat for migrant birds. Pysiol. and Biochem. Zool. 87: 183-195.

Lyons, J. E., Collazo, J. A. and Guglielmo, C. G. 2008. Plasma metabolites and migration physiology of semipalmated sandpipers: refueling performance at five latitudes. Oecologia 155: 417-427.

McWilliams, S. R. and Karasov, W. H. 2001. Phenotypic flexibility in digestive system structure and function in migratory birds and its ecological significance. Comp. Biochem. Physiol. 128A: 579-593.

McWilliams, S. R., Guglielmo, C. G., Pierce, B. J. and Klaassen, M. 2004. Flying, fasting and feeding in birds during migration: a nutritional and physiological ecology perspective. J. Avian Biol. 35: 377-393.

Ogden, L. J., Martin, K. and Williams, T. D. 2013. Elevational differences in estimated fattening rates suggest that high-elevation sites are high-quality habitats for fall migrants. Auk 130: 98-106.

Piersma, T. and Jukema, J. 1990. Budgeting the flight of a long-distance migrant: changes in nutrient reserve levels of bar-tailed godwits at successive spring staging sites. Ardea: 78: 315-337.

Ramenofsky, M. 1990. Fat storage and fat metabolism in relation to migration. Bird migration: physiology and eco-physiology (ed. E. Gwinner), pp 213231. Berlin: Springer. 
Robin, J. P., Frain, M., Sardet, C., Groscolas, R. and Le Maho, Y. 1988. Protein and lipid utilization during long-term fasting in emperor penguins. Am. J. Physio1. 254: R61-R68.

Robinson, D. S. 1970. The function of the plasma triglycerides in fatty acid transport. In: Florkin M, Stotz, E. H. (eds). Comprehensive biochemistry, vol 18. Elsevier, Amsterdam London New York, pp 51-105.

Robinson, A. M. and Williamson, D. H. 1980. Physiological roles of ketone bodies as substrates and signals in mammalian tissues. Physiol. Reviews 60:143-187.

San Francisco, S. 2016. Time activity and energy budgets of Eared Grebes (Podiceps nigricollis) at Salton Sea. Thesis, University of San Diego. San Diego, California, USA.

Scow, R. O. and Chernik, S. S. 1970. Metabolism, transport and utilization of free fatty acids. In: Florkin M. and Stotz, E. H. (eds). Comprehensive Biochemistry, Elsevier, Amsterdam, vol. 18: 19-50.

Seaman, D. A., Guglielmo, C. G. and Williams, T. D. 2005. Effects of physiological state, mass change and diet on plasma metabolite profiles in the western sandpiper Calidris mauri. J. Exp. Biol. 208: 761-769.

Smith, S.B. 2007. Patterns of fuel use and storage in songbirds in relation to diet composition and food availability during migration. (Dissertations and masters theses) Paper AAI3277015.

Smith, S. B. and McWilliams, S. R. 2009. Dietary macronutrients affect lipid metabolites and body composition of a migratory passerine, the white- 
throated sparrow (Zonotrichia albicollis). Physiol. And Biochem. Zool. 82: 259-269.

Smith, S. B. and McWilliams, S. R. 2010. Patterns of fuel use and storage in migrating passerines in relation to fruit resources at autumn stopover sites. Auk 127: 108-118.

Storer, R.W. and Jehl, J.R. 1985. Moult Patterns and moult migration in the Black-Necked Grebe Podiceps nigricollis. Ornis Scandinavica 16: 253-260.

Schwilch, R., Jenni, L. and Jenni-Eiermann, S. 1996. Metabolic responses of homing pigeons to flight and subsequent recovery. J. Comp. Physiol. B 166: $77-87$.

Thomas, N. E. and Swanson, D. L. 2013. Plasma metabolites and creatine kinase levels of shorebirds during fall migration in the prairie pothole region. Auk: 130: $580-590$.

Vehrencamp, S. L., Bradbury, J. W. and Gibson, R. M. 1989. The energetic cost of display in male sage grouse. Animal Behaviour 38: 885-896.

Warnock, J. 2010. Stopping vs. Staging: the difference between a hop and a jump. J. Avian Biol. 41: 621-626.

Williams, T. D., Warnock, N., Takekawa, J. Y. and Bishop, M. A. 2007. Flywayscale variation in plasma triglyceride levels as an index of refueling rate in spring-migrating western sandpipers (Calidris mauri). Auk 124: 886-897.

Wolfe, R.R., Klein, S., Carraro, F. and Weber, J.M. 1990. Role of triglyceridefatty acid cycle in controlling fat metabolism in humans during and after exercise. Am. J. Physiol. 258: E382-E389. 
